\title{
Expression of GnRH type II is regulated by the androgen receptor in prostate cancer
}

\author{
S Darby, J Stockley, M M Khan ${ }^{1}, C$ N Robson, H Y Leung and V \\ $\checkmark$ Gnanapragasam
}

\author{
Urology Research Group, Northern Institute for Cancer Research, Paul O'Gorman Building, Medical School, University of Newcastle \\ Upon Tyne, Framlington Place, Newcastle Upon Tyne NE2 4HH, UK \\ ${ }^{1}$ Department of Pathology, Royal Victoria Infirmary, Queen Victoria Road, Newcastle upon Tyne NE4 6BE, UK \\ (Correspondence should be addressed to V J Gnanapragasam; Email: v.j.gnanapragasam @ncl.ac.uk)
}

\begin{abstract}
$\mathrm{GnRH}$ II has important functional effects in steroid hormone-dependent tumours. Here we investigated the expression and regulation of $\mathrm{GnRH}$ II in prostate cancer. $\mathrm{GnRH}$ II protein was equally expressed in benign $(73 \%)$ and malignant $(78 \%)$ biopsies studied in a prostate tissue microarray $(P=0.779)$. There was no relationship between expression and clinical parameters in the cancer cohort. GnRH II was, however, significantly reduced in tumour biopsies following hormone ablation. This was further investigated in a prostate xenograft model where androgens increased GnRH II levels, while their withdrawal reduced it. In cell lines, we confirmed high levels of GnRH II in androgen receptor (AR)-positive LNCaP cells but low levels in AR-negative PC3 cells. In LNCaP cells, $\mathrm{GnRH}$ II induction by androgens was blocked by the AR inhibitor casodex, but not by cycloheximide treatment. Sequence analysis subsequently revealed a putative androgen response element in the upstream region of the $G n R H$ // gene and direct interaction with the AR was confirmed in chromatin immunoprecipitation experiments. Finally, to test whether the effects of $\mathrm{GnRH}$ II were dependent on AR expression, $\mathrm{LNCaP}$ and $\mathrm{PC} 3$ cells were exposed to exogenous peptide. In both cell lines, GnRHII inhibited cell proliferation and migration, suggesting that its function is independent of AR status. These results provide evidence that $\mathrm{GnRH} I \mathrm{I}$ is widely expressed in prostate cancer and is an $A R$ regulated gene. Further studies are warranted to characterise the effects of $\mathrm{GnRH}$ II on prostate cancer cells and investigate its potential value as a novel therapy.
\end{abstract}

Endocrine-Related Cancer (2007) 14 613-624

\section{Introduction}

Prostate cancer remains the most commonly diagnosed malignancy and the second leading cause of cancerrelated deaths among men in the USA (Jemal et al. 2006). Gonadotrophin-releasing hormone I (GnRH I) analogue therapy is an important mode of treatment for men with locally advanced and metastatic disease. The GnRHGnRH receptor (GnRHR) axis, however, may have a more direct anti-tumourigenic effect. In particular, GnRH I has been shown to have both anti-proliferative and anti-metastatic effects on prostate cancer cells (Dondi et al. 1998, Limonta et al. 1999). This effect may also be active in the hormone-refractory stages of clinical disease (Gnanapragasam et al. 2005).

A second form of GnRH, GnRH II, was first reported in humans by White et al. (1998). The gene is located on chromosome 20 and includes four exons and three introns coding for a 10-amino acid sequence. In some mammals, GnRH II is involved in sexual function and reproduction, but its role in humans is less clear (Temple et al. 2003). In localisation studies, GnRH II has been found throughout the human central nervous system, but is also widely expressed in peripheral tissue. This suggests a hitherto unrecognised role for GnRH II in peripheral cell function (White et al. 1998). Intriguingly, expression levels in the prostate were found to be four times higher than in the brain. It has recently been shown that GnRH II has anti-proliferative effects on both ovarian and endometrial cancer cells (Choi et al. 2001, Grundker et al. 2002, 2004). Similar effects have also been reported following GnRH II treatment of breast cancer cells (Gunthert et al. 2005). These data suggest that GnRH II may have important anti-tumourigenic effects in steroid hormone-dependent malignancies. In this context, the role of GnRH II 
in prostate cancer is of particular interest, especially in view of evidence of high expression in the prostate.

The expression and regulation of GnRH II in prostate cells is currently unknown. To investigate this, we undertook a study of GnRH II in a clinical cohort of benign and malignant prostate biopsies as well as in in vitro and in vivo models of prostate cancer.

\section{Materials and methods}

\section{Cell culture}

Prostate cancer cell lines were maintained in RPMI 1640 media (Sigma) containing 10\% FCS (FM-full medium). Basal media (BM) was RPMI 1640 alone. For experiments requiring androgen-depleted medium, dextran-coated charcoal (DCC) was first used to remove endogenous steroids present in FCS (DCC medium). LNCaP cells (derived from a lymph node metastasis) were chosen for androgen induction studies as a model of hormone-sensitive prostate cancer (Horoszewicz et al. 1983). These cells display androgen-dependent growth characteristics and abundantly express the androgen receptor (AR). LNCaP cells grown in DCC media for $48 \mathrm{~h}$ were termed LNCaP-AD (androgen depleted). LNCaP-AI (androgen-independent) cells have been previously described (Halkidou et al. 2003).

\section{Quantitative real-time PCR (QPCR)}

Quantitative mRNA expression was evaluated through real-time PCR using a 7900-HT sequence detection system (Applied Biosystems, Foster City, CA, USA). Total RNA extracted from cell lines was first treated with MMLV Reverse Transcriptase reaction cocktail (Promega) according to manufacturer's instructions. QPCR was performed by Jumpstart SYBR Green mastermix (Sigma) and primers designed using primer express 2.0 (Applied Biosystems) as follows: GnRH II forward $5^{\prime}$ CAGAACTTC GGCTTCCGTTT $3^{\prime}$ and reverse $5^{\prime}$ CTGCTCACAGGTCTTTCGCTTG 3', GAPDH forward $5^{\prime}$ CGACCACTTTGTCAAGCTCA $3^{\prime}$ and reverse $5^{\prime}$ GGGTCTTACTCCTTG GAGGC 3', PSA forward 5' GGTGCATTACCGGAAGTGGAT $3^{\prime}$ and reverse $5^{\prime}$ TGGTCATTTCCAAGGTTCCAAG $3^{\prime}$, F1R1 forward $5^{\prime}$ GCTTTC TATGTTCTAATGAGAGGGATA $3^{\prime}$ and reverse $5^{\prime}$ TCCTGAAAAATCTAAACCAGA GCC $3^{\prime}$, F2R2 forward $5^{\prime}$ TAAACAGGCCTCTGACCCCC $3^{\prime}$ and reverse $5^{\prime}$ TACCTA CCCCGGAGTGGCT $3^{\prime}$ and ARE I forward $5^{\prime}$ CCTAGATGAAGTCTCCATGAGCTACA $3^{\prime}$ and reverse $5^{\prime}$ GGGAGGGAGAGCTAGCACTTG $3^{\prime}$. The level of expression was evaluated using the absolute quantification method normalising against the housekeeping gene GAPDH (ABI technical bulletin 2, www.appliedbiosystems.com).

\section{Immunohistochemistry}

A prostate tissue microarray (TMA) was constructed from $0.6 \mathrm{~mm}$ cores of benign $(n=37)$ and malignant samples $(n=123)$. Primary cancer biopsies were derived from hormone treatment in naïve patients either from transurethral resection of the prostate or radical prostatectomy. A further 35 patients had sequential biopsies available, of which 27 had received interim androgen ablation. In 13 of these patients, the second biopsy was obtained after the onset of hormone-refractory disease as defined by a sequential rise in the PSA. Immunohistochemistry was performed by GnRH II polyclonal antibody (Santz Cruz, Biotechnology Inc., Santa Cruz, CA, USA). The optimal antibody concentration was derived from dilution testing on composite tissue blocks (final concentration 1:100). Antigen retrieval was achieved by immersion in $0.01 \mathrm{M}$ sodium citrate buffer ( $\mathrm{pH}$ 6.0) and microwaving for $1 \mathrm{~min}(1000 \mathrm{~W})$ in a pressure cooker. Sections incubated without primary antibody were employed as internal negative controls. Secondary antibody labelling was achieved using biotinylated antibodies (Dako, Ely, UK). All sections were counterstained with DAB and haematoxylin. Immunostained sections were studied without prior knowledge of the clinical details. Sample sections were viewed by two independent observers (VJ Gnanapragasam, MM Khan) and inter-observer agreement was obtained regarding a grading system. The level of GnRH II expression was correlated with the strength of the immunoreactivity signal and was scored as either absent $(0)$, weak $(+)$, moderate $(++)$ or strong $(+++)$. Where two or more signal intensities were present in one case, the predominant signal was taken as the score. The use of all tissue and patient data was in accordance with the approval granted by the local hospital's ethics committee. Statistical analysis was performed by correlating expression with clinical parameters using the $\chi^{2}$ test. $P<0.05$ was taken as being statistically significant.

\section{Case Western Reserve (CWR22) model}

The CWR22 xenograft model is an androgen-dependent tumour derived from a high Gleason grade prostate cancer. AR expression is preserved, and tumour cell growth and PSA expression in this model are exquisitely androgen sensitive (Wainstein et al. 1994, Kim et al. 2002). The use of this model in our unit has been previously described (Gnanapragasam et al. 2002). Briefly, cell suspensions 
were mixed with Matrigel (Collaborative Research, Bedford, MA, USA) before s.c. injection into 12- to 16-week-old CD 1 male nude mice (Charles Rivers, Wilmington, MA, USA). Following tumour growth for 6 weeks, mice were randomly allocated into three groups. The first group received s.c. implantation of sustained release testosterone pellets (Innovative Research of America, Sarasota, Fl, USA). The second group was castrated by bilateral orchidectomy and the third group was sham anaesthetised only. Initial tumour volumes between the groups were not significantly different $(P<0.05)$. Tumours were harvested at week 4 , carefully dissected, denuded of host mouse tissue and fixed in paraffin. The $5 \mu \mathrm{m}$ sections were cut onto APES-coated slides for further study. GnRH II and PSA expressions were determined by immunohistochemistry using GnRH II and PSA antibodies (Santz Cruz) diluted 1:100 as described previously.

\section{Androgen induction assays}

LNCaP and LNCaP-AI cells were seeded at a density of $5 \times 10^{4}$ cells/well in 6-well plates. Cells were grown in either DCC medium or DCC media containing the synthetic androgen $10 \mathrm{~nm}$ R1881 (Perkin-Elmer, Waltham, MA, USA). Where appropriate, cells were also pretreated with $10 \mu \mathrm{M}$ casodex. Androgen induction experiments were also repeated in the presence of $1 \mu \mathrm{M}$ cycloheximide. GnRH II immunofluorescence was performed by seeding $5 \times 10^{3}$ cells/well in 8-well chamber slides (Becton-Dickinson, Oxford, UK) and growing them in either DCC medium, DCC media containing R1881 or full media in the absence or presence of casodex for $48 \mathrm{~h}$. The cells were then fixed with $100 \%$ methanol for $20 \mathrm{~min}$ at $-20{ }^{\circ} \mathrm{C}$ and were then incubated with the GnRH II polyclonal antibody overnight. They were washed in PBS and treated with secondary antibody diluted 1:200 for $1 \mathrm{~h}$. Slides were mounted with Vectashield containing DAPI as a nuclear counterstain. Statistical analysis was performed by two-tailed Student's $t$-test. $P<0.05$ was taken as being statistically significant.

\section{Chromatin immunoprecipitation (CHIP) assays}

LNCaP cells were grown in DCC media for $72 \mathrm{~h}$ and were then stimulated with $10 \mathrm{nM} \mathrm{R} 1881$ for $6 \mathrm{~h}$. CHIP assays were performed as described previously (Gaughan et al. 2002). For immunoprecipitation, $2 \mu \mathrm{g}$ polyclonal AR antibody (Sigma) were used as indicated. Real-time PCR was performed using $10 \mu \mathrm{l}$ DNA from each sample against ARE I, F1R1 and F2R2 primers and compared with non-immunoprecipitated samples and input samples.

\section{Proliferation and migration assays}

LNCaP and PC3 cells were seeded at a density of 3000 cells/well in 96-well plates (Corning). The cells were grown in full media containing 0-500 nM GnRH II (Bachem, GmbH, Weil am Rhein, Germany). WST 1 reagent (Roche) was then added in a 1:10 dilution and colorimetric change was measured at $410 \mathrm{~nm}$ on a Specta Max 250 plate reader (Molecular Devices, Sunnyvale, CA, USA). In migration assays, LNCaP and PC 3 cells were plated out at a density of 50000 cells into BD Falcon migration chambers in basal media with $0-1 \mu \mathrm{M}$ GnRH II. Full media was used in the lower chamber as the chemoattractant. Cells were allowed to invade for $24 \mathrm{~h}$ in a humidified tissue culture incubator. Non-invading cells were removed from the upper chamber and invaded cells were fixed in methanol for $20 \mathrm{~min}$ at $-20{ }^{\circ} \mathrm{C}$ and stained with haematoxylin. Membranes were removed with a sterile scalpel and mounted onto slides with DPX and counted using a bright field microscope ( $20 \times$ magnification). A minimum of four different fields of view were used to obtain an average count per section. Statistical analysis was performed by two-tailed Student's $t$-test. $P<0.05$ was taken as being statistically significant.

\section{Results}

\section{GnRH II protein expression in clinical benign and malignant prostates}

GnRH II antibody was optimised for immunohistochemistry and tested against a panel of normal tissue. Strong signals were seen in sections of kidney (positive control), while the lung (negative control) failed to express the protein (Fig. 1A). This is consistent with previous reports of expression in human tissue (White et al. 1998). In prostate tissue, expression was seen predominantly in epithelial cells with no expression in stromal tissue (Fig. 1A). In the prostate TMA, GnRH II expression was seen in 73\% (27/37) of benign biopsies and 78\% (96/123) of primary cancer biopsies $(P=0.779$; Table 1$)$. Expression of GnRH II in the cancer group was further stratified by the intensity of staining. The levels of $\mathrm{GnRH}$ II expression were variable in the group with no correlation of staining intensity with Gleason grade or clinical stage of the disease ( $P=0.067$ and 0.334 respectively; Table 1$)$. GnRH II expression was also not associated with PSA at presentation, metastasis or overall survival. In a subset of cancers, at least two sequential biopsies were available from the same patient (Table 1). In eight cancers, no treatment had been given in the interval between biopsies, while 14 patients had received androgen ablation therapy with the second biopsy taken during the hormone-sensitive 

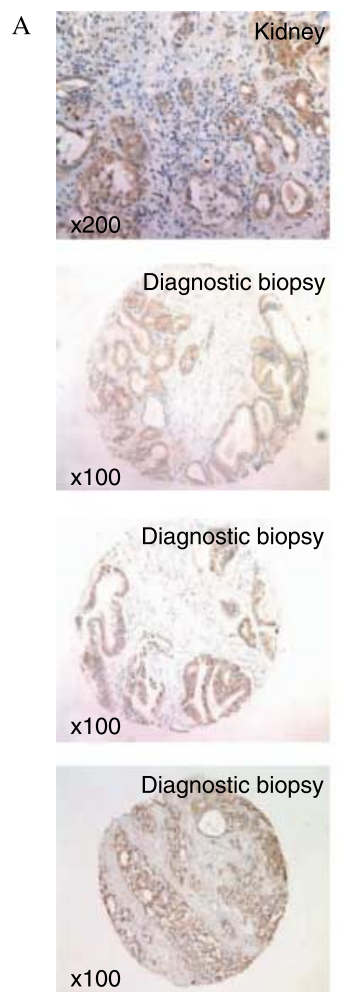

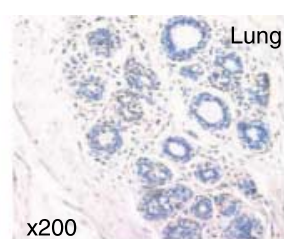

No treatment

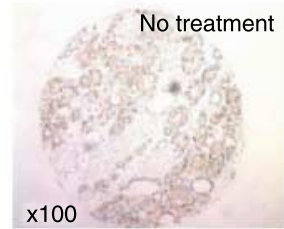

Post androgen ablation -Hormone sensitive

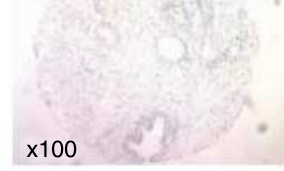

Post androgen ablation -Hormone relapse

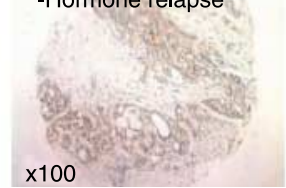

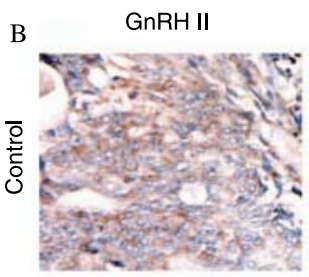
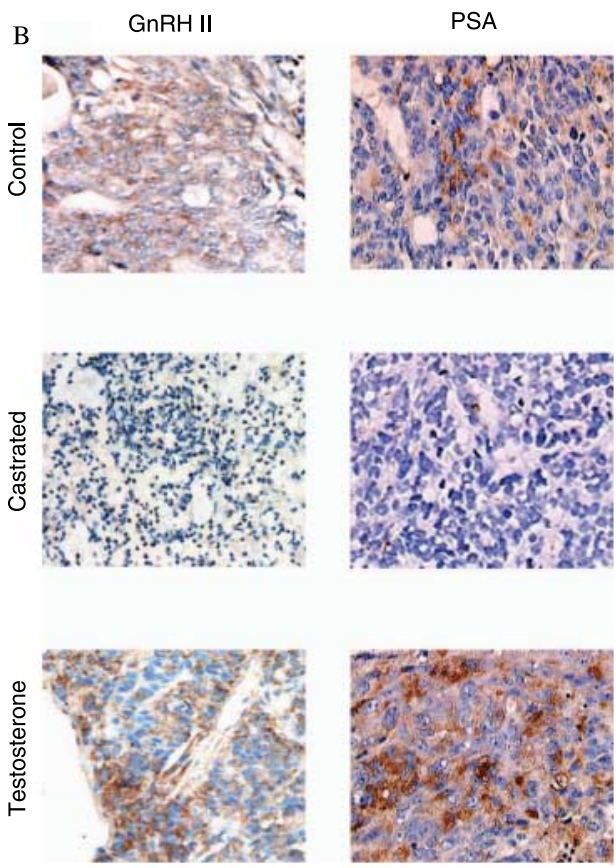

Figure 1 In vivo levels of $\mathrm{GnRH}$ II protein is related to androgen status. (A) Strong positive signals in kidney with no expression in lung tissue. Immunohistochemistry in matched biopsy cores before and after androgen ablation. Representative biopsies from both hormone-sensitive and hormone-relapsed cases are shown. (B) Immunostaining in CWR22 prostate xenograft tumours following sham anaesthetic, surgical castration or testosterone implants.

stage of the disease. The effect of castration in the treatment group was confirmed by a significant reduction in serum PSA expression following the treatment (data not shown). In this cohort, we unexpectedly observed that in the post-treatment biopsies all initially positive tumours failed to express GnRH II (Table 1 and Fig. 1A). This result was independent of whether castration had been achieved medically $(n=7)$ or surgically $(n=4)$. In contrast, in the group that had not received treatment, there was no difference in GnRH II expression between the first and second biopsies. We next studied expression in a cohort of 13 hormone-refractory prostate cancers. These patients also had biopsies available from the point of diagnosis and were positive for GnRH II in eight cases. Among these, subsequent matched biopsies taken during the hormone-refractory stage of the disease was positive for GnRH II in 4/8 (50\%) cases (Fig. 1A). These results suggest that GnRH II is frequently expressed in benign and malignant prostate glands. Expression is not dependent on disease grade or stage but is significantly reduced following hormone ablation. In hormone-refractory disease however, GnRH II is re-expressed in a significant number of cancers.

\section{GnRH II in prostate cancer cells is regulated by androgen stimulation}

An in vivo model of prostate cancer was used to test the interaction between androgens and GnRH II. The CWR22 human prostate xenograft model is particularly sensitive to androgen manipulation. $\mathrm{GnRH}$ II levels were investigated in tumours from surgically castrated mice and those that had been given testosterone supplements. GnRH II levels were significantly reduced in tumours from castrate mice compared with untreated controls (Fig. 1B). In contrast, expression was significantly higher in tumours from mice that had received testosterone supplements. PSA protein levels showed a similar pattern and acted as a control for the experiment (Fig. 1B). GnRH II was next studied in a panel of prostate cancer cell lines. Highest levels of mRNA expression were seen in AR-positive LNCaP cells with lower levels in AR-negative DU145 and even lower levels in AR-negative PC3 cells (Fig. 2A). We then tested the effect of androgen manipulation on LNCaP cells. In this experiment, GnRH II and PSA mRNA levels were significantly down-regulated in a time-dependent manner following androgen withdrawal (Fig. 2B). 
Table 1 Gonadotrophin-releasing hormone II (GnRH II) protein expression in a clinical cohort of benign and malignant prostates

GnRH II negative

GnRH II positive

\begin{tabular}{llll}
\hline All biopsies $(n=165)$ & & & \\
Benign $(n=37)$ & 10 & 27 & $P=0.779$ \\
Cancer $(n=123)$ & 27 & 96 & $P$ \\
\hline
\end{tabular}

\begin{tabular}{|c|c|c|c|c|c|}
\hline & \multicolumn{4}{|c|}{ GnRH II score } & \\
\hline & \multirow{2}{*}{$\begin{array}{c}\text { Negative } \\
0\end{array}$} & \multicolumn{3}{|c|}{ Positive } & \\
\hline & & + & ++ & +++ & \\
\hline \multicolumn{6}{|c|}{ Cancer biopsies $(n=123)$} \\
\hline Gleason grade 3 & 9 & 5 & 16 & 3 & \multirow{6}{*}{$P=0.067$} \\
\hline Gleason grade 4 & 4 & 17 & 21 & 8 & \\
\hline Gleason grade 5 & 14 & 10 & 13 & 3 & \\
\hline Stage 1 & 11 & 6 & 20 & 6 & \\
\hline Stage 2 & 6 & 7 & 8 & 3 & \\
\hline Stage 3 & 6 & 15 & 12 & 2 & \\
\hline \multirow[t]{2}{*}{ Stage 4} & 4 & 4 & 10 & 3 & $P=0.334$ \\
\hline & \multicolumn{3}{|c|}{ GnRH II negative } & \multicolumn{2}{|c|}{ GnRH II positive } \\
\hline \multicolumn{6}{|c|}{ Matched cancer biopsies $(n=22)$} \\
\hline \multicolumn{2}{|l|}{ Diagnostic TURP } & \multicolumn{2}{|c|}{3} & \multicolumn{2}{|c|}{5} \\
\hline \multicolumn{2}{|c|}{ Second TURP-no treatment } & \multicolumn{2}{|c|}{3} & \multicolumn{2}{|c|}{5} \\
\hline \multicolumn{2}{|c|}{ Diagnostic TURP } & \multicolumn{2}{|c|}{3} & \multicolumn{2}{|c|}{11} \\
\hline \multicolumn{2}{|c|}{ Second TURP-post-androgen ablation } & \multicolumn{2}{|c|}{14} & \multicolumn{2}{|c|}{0} \\
\hline
\end{tabular}

$\mathrm{GnRH}$ II was scored as either being absent (negative) or present (positive) in analysis of benign and malignant prostates. In the cancer cohort, intensity of signals were scored as negative $(0)$, mild $(+)$, moderate $(++)$ or strong $(+++)$. A $P$ value of $<0.05$ was taken as significant. In matched cancers, the second biopsy was available from untreated patients or post-androgen ablation patients with either hormone-sensitive or hormone-relapsed disease as shown (stage - clinical stage).

Conversely, treating androgen-deprived cells with increasing doses of a synthetic androgen (R1881) resulted in a strong induction of GnRH II and PSA mRNA levels (Fig. 2C). The LNCaP AI cell line has been previously described and is serially maintained in androgen-free media. AR expression in these cells is preserved and remains highly responsive to ligand stimulation (data not shown). The cells, however, do not rely on androgens for survival. In these cells, GnRH II mRNA was found to be significantly reduced in comparison to parental LNCaP cells (Fig. 2D). Treating these cells with R1881 (synthetic androgen), however, restored expression in a dose-dependent manner (Fig. 2D). We confirmed our findings at the protein level using immunofluorescence. In keeping with our mRNA data, we found high levels of GnRH II protein in LNCaP cells (Fig. 2E). We similarly observed very low GnRH II levels in PC3 cells (data not shown). Both shortterm and long-term androgen deprivation (LNCaP AD and LNCaP AI respectively) significantly reduced endogenous GnRH II protein levels (Fig. 2E). These data suggest that androgens have an important role in regulating GnRH II expression in the prostate cancer cell. This effect is unlikely to be cell type specific as it is observed in clinical samples, prostate xenografts and cultured cell lines.

\section{Androgen induction of GnRH II occurs through the AR}

We next tested whether androgen regulation was a direct or indirect effect. To investigate this LNCaP cells were exposed to androgens and in the presence or absence of the non-steroidal AR antagonist (casodex). In this experiment, R1881 again significantly induced GnRH II mRNA expression. This induction, however, was effectively blocked by co-treatment with casodex (Fig. 3A). A similar result was seen with PSA as a control. These findings were subsequently confirmed at the protein levels. In immunofluorescence studies, GnRH II protein was reduced by androgen depletion (LNCaP AD) but increased with the addition of R1881. This effect was lost when cells were co-incubated with casodex (Fig. 3B). Induction may, however, occur through an intermediary protein. To test this, we again exposed LNCaP cells to androgens following pretreatment with the peptidyl-transferase inhibitor cycloheximide. In these studies, the addition of cycloheximide had no effect on the induction of GnRH II by androgens. There was also 
A
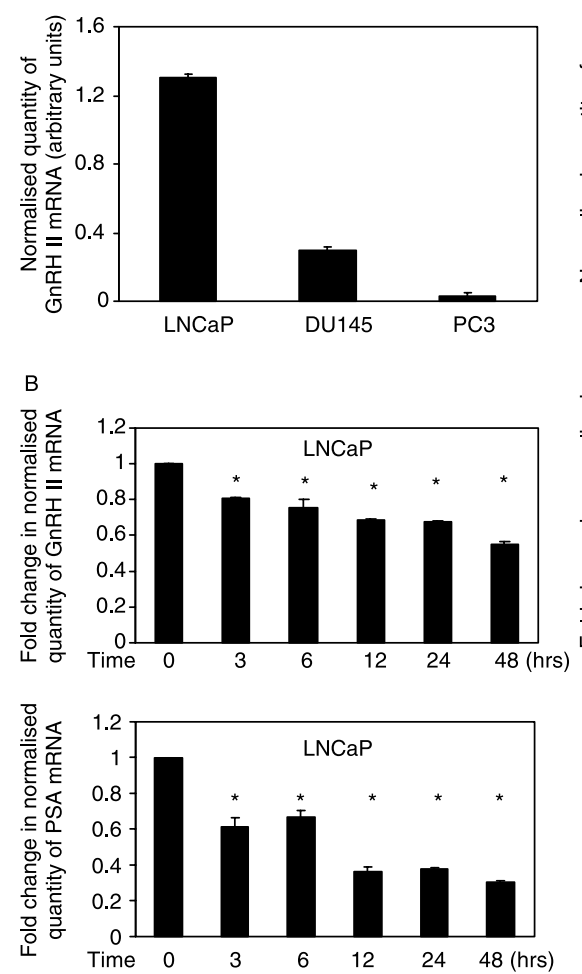

C
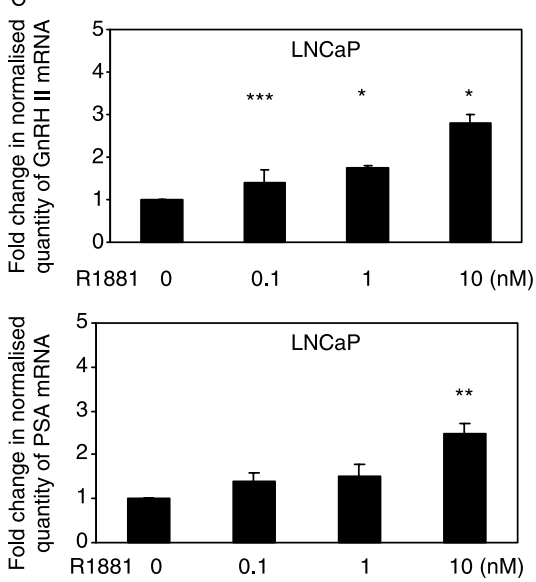

D
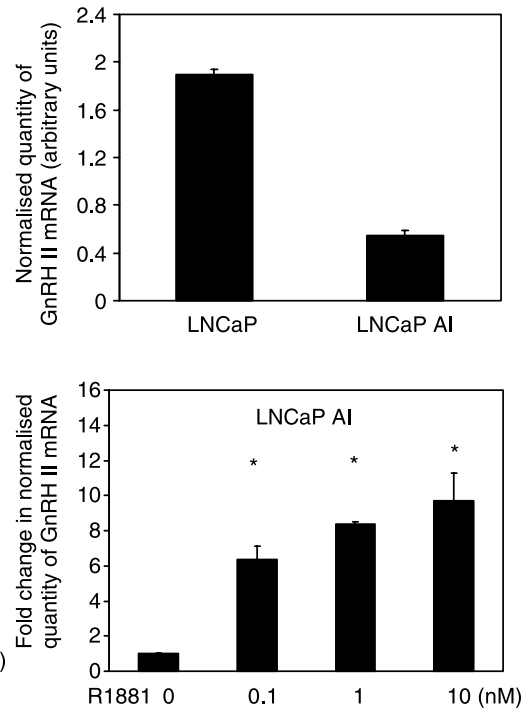

E
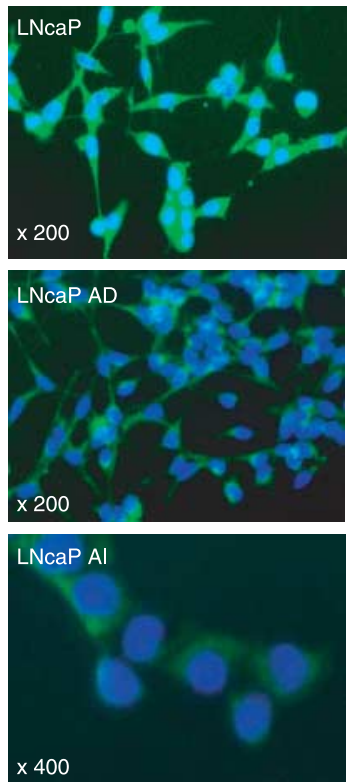

Figure 2 Expression of GnRH II is regulated by the presence or absence of androgens. (A) GnRH II mRNA expression in a panel of prostate cancer cells. (B) LNCaP cells were deprived of androgens and assayed for GnRH II and PSA mRNA at the displayed times. In both experiments, results shown are the mean of three experiments done in triplicate with error bars representing s.D.s. (C) Initially androgen-deprived LNCaP cells were treated with synthetic androgens (R1881) at increasing doses as shown before mRNA extraction at $24 \mathrm{~h}$ and measurement of GnRH II and PSA levels. (D) LNCaP Al cells were obtained by serial culture in an androgenfree environment for at least 8 months. mRNA was extracted and assayed for GnRH II expression and compared with LNCaP controls. LNCaP Al cells were then treated with increasing doses of R1881 for $24 \mathrm{~h}$ before mRNA extraction and measurement of $\mathrm{GnRH}$ II. Results shown are the mean of three experiments each done in triplicate and is expressed as a fold change over un-induced cells (given a value of 1) with error bars representing s.D.s. (E) Corresponding changes in LNCaP GnRH II expression at the protein level were confirmed using immunofluorescence and under the different treatment conditions (green - GnRH II protein, blue - DAPI nuclear stain). One representative of three different experiments is shown here. LNCaP AD, LNCaP androgen depleted for $48 \mathrm{~h}$; LNCaP AI, LNCaP androgen independent as described above. ${ }^{\star} P<0.001,{ }^{\star \star} P<0.005,{ }^{\star \star \star} P<0.05$. 


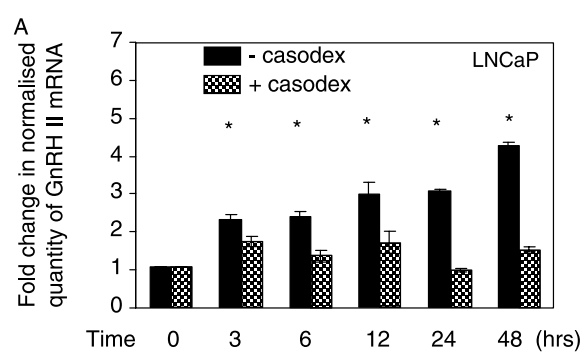

B

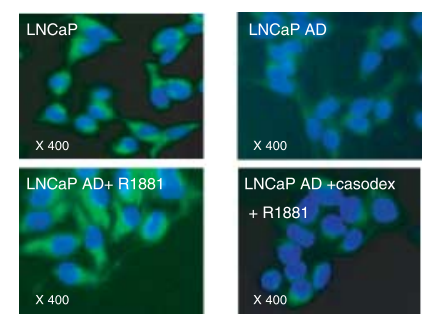

C
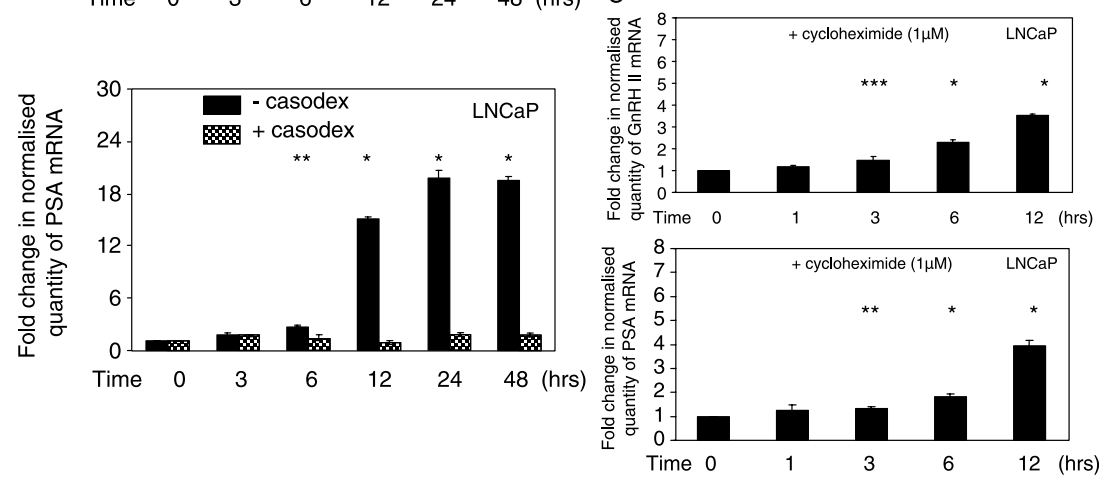

Figure 3 Androgen induction of GnRH II is a direct effect through the androgen receptor. (A) LNCaP cells with and without pretreatment with the AR antagonist casodex $(10 \mu \mathrm{M})$ before the addition of androgens. GnRH II and PSA mRNA were assayed at the displayed times. (B) Protein expression of $\mathrm{GnRH}$ II was assessed by immunofluorescence in LNCaP cells, following androgen deprivation (LNCaP AD) and androgen stimulation with or without casodex treatment. (C) LNCaP cells were treated with androgens as described and with prior administration of cycloheximide. Cells were harvested for mRNA at the defined time points. Results shown are the mean of three experiments each done in triplicate and is expressed as a fold change over un-induced cells (given a value of 1) with error bars representing s.D.s. For immunofluorescence, one representative of three different experiments is shown (green - GnRH II protein, blue - DAPI nuclear stain). ${ }^{\star} P<0.001,{ }^{\star \star} P<0.01,{ }^{\star \star \star} P<0.05$.

no effect seen on the induction of PSA used as a positive control (Fig. 3C). These results suggest that androgendependent regulation of GnRH II requires the AR and is not a secondary effect of AR activation by an intermediary protein.

\section{The GnRH II upstream sequence contains a putative AR binding site}

Our findings raised the possibility of a direct interaction between the $A R$ and the GnRH II genes. Analysis of the GnRH II gene sequence revealed a possible androgen regulatory element (ARE) at position -1383 to -1369 upstream of the translation start codon (Fig. 4A). This motif was found to have a high degree of sequence homology with the consensus DNA binding site for the AR (14) (Fig. 4A). To confirm in vivo interaction between the $\mathrm{AR}$ and this identified sequence, we performed CHIP experiments using an AR antibody followed by QPCR. The primer set F1R1 was designed to cover the sequence of interest, while a second primer set, F2R2, spanned an adjacent region downstream and acted as a negative control. A known ARE sequence (ARE 1 derived from the PSA promoter) was used as a positive control. With primer set F2R2, there was no difference in the amplicon signal using DNA from $\mathrm{LNCaP}$ cells cultured in the presence or absence of androgens (Fig. 4B). QPCR with F1R1, however, produced a significantly stronger signal with template from androgen-treated LNCaP cells as compared with untreated controls (Fig. 4B). Similar high amplicon signals were obtained using primers for the ARE1-positive control in androgen-treated cells. There was no difference in the signal strength when primer sets F1R1, F2R2 or ARE1 were amplified in input samples isolated prior to immunoprecipitation (Fig. 4C). These results suggest that the presence of an AR binding site in the region spanned by F1R1 and correspond to the presence of identified putative ARE in this sequence.

\section{Exogenous GnRH II exerts similar effects on both androgen-dependent and androgen-independent prostate cancer cells}

GnRH II has been shown to have anti-tumourigenic effects in a number of steroid-dependent tumours. We therefore asked whether this effect occurred in prostate cancer and was influenced by the AR status of the cell. This was investigated by adding exogenous GnRH II to 
A
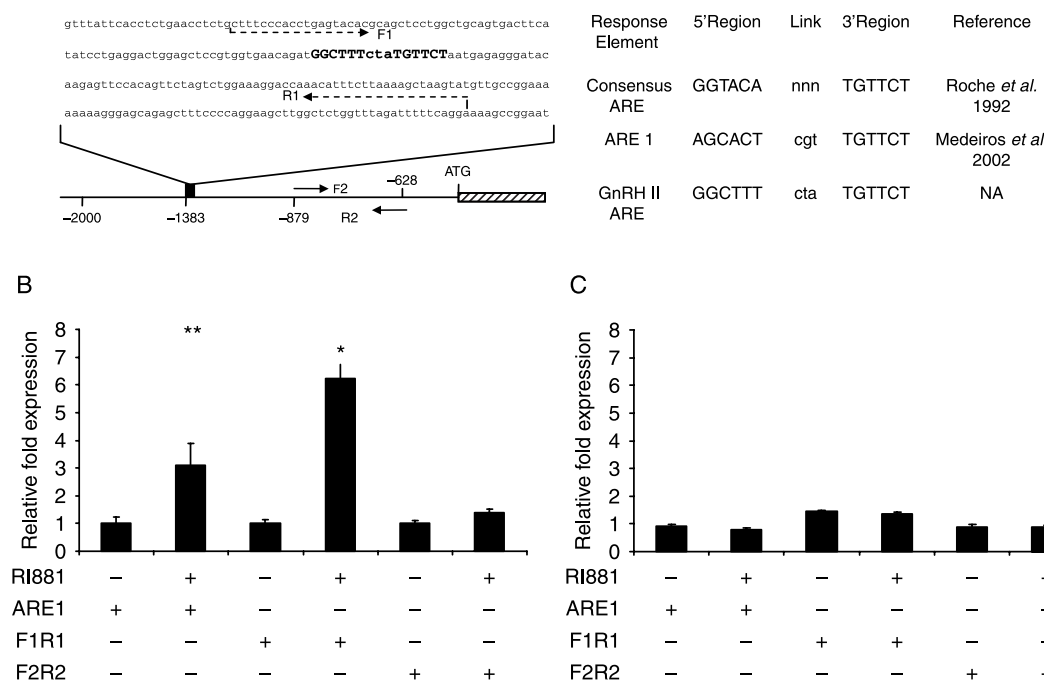

C

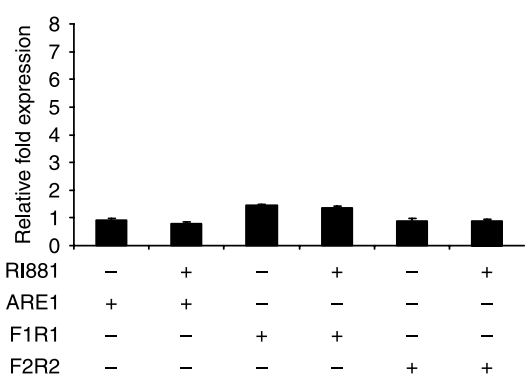

Figure 4 The GnRH II upstream sequence contains a putative ARE. (A) The $5^{\prime}$ upstream region was identified and analysed for AR binding sites. The sequence was compared with the published consensus ARE and the positive control ARE 1. (B) QPCR was performed on LNCaP chromatin immunoprecipitated with the AR antibody in the presence or absence of androgens. Primers were used for F1R1, F2R2 and the control ARE 1. Non-androgen-stimulated samples were assigned the value of 1 and androgenstimulated samples compared as a fold change with error bars representing S.D.s. All values were normalised against input samples as a control. (C) Similar experiments on input chromatin were used to ensure equal DNA loading. In both experiments, results shown are one of three repeat tests with androgen exposure for $24 \mathrm{~h}$. ${ }^{\star} P<0.001,{ }^{\star \star} P<0.01$.

AR-positive (LNCaP) and AR-negative (PC3) prostate cancer cell lines. GnRH II significantly inhibited LNCaP cell proliferation by up to $50 \%$ in a dosedependent manner $(P<0.005$; Fig. 5A). In PC3 cells, GnRH II treatment again resulted in an up to $40 \%$ reduction in cell proliferation $(P<0.005$; Fig. $5 \mathrm{~B})$. We next tested, the effect of GnRH II on cell migration using full media as a stimulus. In these experiments, exogenous GnRH II efficiently reduced the migration of $\mathrm{LNCaP}$ cells through a porous membrane by up to $50 \%(P<0.005$; Fig. 5C). This effect was most pronounced at higher treatment doses, but it was also
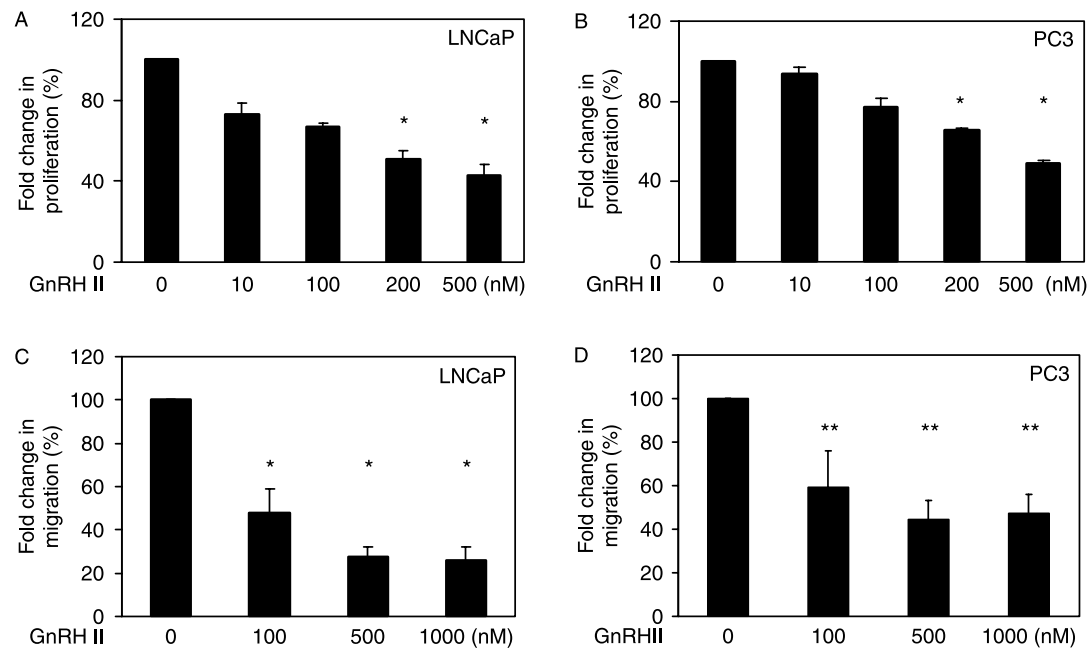

Figure 5 Effect of exogenous GnRH II on AR-positive and AR-negative prostate cancer cells. (A and B) LNCaP and PC3 cells were cultured in full media with increasing doses of $\mathrm{GnRH}$ II as shown. Cell proliferation was measured using WST 1 assays. (C and D) LNCaP and PC3 cells were cultured in migration chambers with full media as a chemoattractant. GnRH II was then added in increasing doses as shown. In all studies, results shown are the mean of three experiments each done in triplicate and is expressed as a fold change over un-induced cells (given a value of $100 \%$ ) with error bars representing s.D.s. ${ }^{\star} P<0.005,{ }^{\star \star} P<0.001$. 
effective at a dose of $100 \mathrm{nM}$. In PC3 cells, a similar inhibitory effect was seen with an up to $75 \%$ reduction in cell migration in the presence of GnRH II $(P<0.001$; Fig. 5D). These results show evidence that exogenous GnRH II exerts both anti-proliferative and anti-migratory effects on prostate cancer cells. Of note, this effect appears to be independent of whether cells were AR positive or negative suggesting that GnRH II signalling mechanism are likely to be functionally intact in both.

\section{Discussion}

A number of studies have suggested that GnRH I and GnRH II as well as the GnRHR are regulated by gonadotrophins and steroid hormones. Choi et al. (2006) have recently shown that gonadotrophins follicle-stimulating hormone and luteinizing hormone (FSH and LH) are able to reduce the levels of GnRH II but not GnRH I mRNA in ovarian surface epithelium and cancer cell lines. Gonadotrophin treatment also reduced the expression of the type I GnRHIR in these cells. Nathwani et al. (2000) have shown that oestrogens can down-regulate GnRH I expression in ovarian granulosa-luteal cells. Conversely, oestrogens actually increase the expression of GnRH II in these cells and in human neuronal cells (Chen et al. 2002a, Khosravi \& Leung 2003). Oestrogens also appear to have a suppressive effect on GnRHIR expression possibly by a direct effect on the gene promoter (Nathwani et al. 2000, Kang et al. 2001). Progesterone acting through specific receptor isoforms has been shown to be a potent regulator of GnRH I and GnRHIR expressions but appears to have no effect on GnRH II (An et al. 2005). Androgen treatment has been shown to down-regulate GnRH I expression in a timedependent fashion in hypothalamic neuronal cells (Belsham et al. 1998). GnRHIR, however, is not influenced by androgen treatment in work done in prostate cells (Gnanapragasam et al. 2005).

In this study, we found GnRH II protein expression in the majority of both normal and malignant prostate glands. There was no association between the expression and the tumour grade or stage in the sub-analysis of the cancer cohort. This is in contrast to breast tissue where expression has been found in both normal and neoplastic cells but is significantly higher in malignant tissue (Chen et al. 2002b). We did observe, however, that GnRH II protein expression was significantly down-regulated in patients who had been treated by androgen withdrawal therapy. We further confirmed this observation of androgen responsiveness in a human prostate xenograft model. A possible direct effect of $\mathrm{GnRH}$ analogues on
GnRH II expression is unlikely, as androgen withdrawal was achieved in the animal model and in some clinical samples by surgical castration. Androgen induction was further tested using in vitro models. Here both mRNA and protein expressions of GnRH II were induced by androgens acting directly through the AR. Conversely, androgen withdrawal significantly reduced GnRH II levels. This is in contrast to the inhibitory effects of androgens on hypothalamic GnRH I expression and the lack of effect on GnRHIR expression.

The human GnRH II promoter has been previously characterised (Cheng et al. 2003). The minimal promoter is located between -1124 and $-750 \mathrm{bp}$ upstream of the translation start codon. The untranslated first exon is also thought to be important for full promoter activity (acting as an enhancer). Our analysis of the sequence proximal to the ATG revealed a putative androgen response element (ARE) which is further upstream of this minimal promoter region. We have previously observed a similar arrangement with the androgen-sensitive FGF8 gene promoter where the hormone response region is distinct from the active promoter (Gnanapragasam et al. 2002). Furthermore, Chen et al. (2001) have previously identified a cAMP response element at positions -67 to -60 upstream of the GnRH II start codon and hence separate from the active promoter. It is possible that conformational changes in the gene following steroid hormone binding might bring the ARE into closer proximity with the active promoter and may also involve recruitment of the enhancer region in exon 1 . Such an arrangement has been recently proposed for the PSA promoter (Wang et al. 2005). In CHIP experiments, the sequence incorporating this putative ARE bound to the AR protein at comparable levels to a known ARE in cells stimulated with androgens. These observations in clinical, in vivo and in vitro, models provide compelling evidence that GnRH II is an androgen-regulated gene. We also found evidence that in contrast to androgen ablated hormone-sensitive cancers, GnRH II was expressed in a subset of biopsies from patients with androgen-independent prostate cancer. Based on our findings, we hypothesise that this is likely to be related to a reactivated AR signalling pathway, which is an important feature in the development of hormone-refractory disease (Grossmann et al. 2001, Cronauer et al. 2003).

In this study, GnRH II treatment inhibited prostate cancer cell proliferation regardless of the AR status. Furthermore, GnRH II was also capable of reducing the migratory ability of these cells, a key step in tumourigenesis and metastasis. The fact that GnRH II is induced by the AR and yet has inhibitory effects in prostate cells is indeed paradoxical. The AR, however, has been shown to have growth inhibitory effects in 
differentiated benign epithelial cells (Rossi et al. 1996, 1998). In the normal prostate, it is also though to have tumour suppressive effect and inhibit excess proliferation of luminal cells (Ling et al. 2001, Whitacre et al. 2002, Litvinov et al. 2006). We hypothesise that the induction of GnRH II by the AR may be a part of this homeostatic mechanism to regulate the level of prostate cell stimulation. This homeostatic mechanism, however, is unlikely to be effective in preventing the development of hormone-sensitive cancer. GnRH II may therefore not have a role in hormone-sensitive cancers at physiological levels of expression. Expression may also be further lowered by androgen withdrawal therapy which might further facilitate overactivity in kinase pathways because of the loss of an endogenous regulatory mechanism. In this context, exogenous treatment with non-physiological doses of GnRH II might prove a useful therapy to directly inhibit androgen-dependent cancers perhaps, as an adjunct to androgen withdrawal. Similarly, although we have detected endogenous GnRH II in androgenindependent cancers the levels of expression may be insufficient to effectively inhibit tumour cells. GnRH II may therefore also have a role in hormone-refractory disease and this is supported by our observation of its anti-tumourigenic effect on both androgen-dependent and androgen-independent prostate cancer cells.

The mechanism by which GnRH II inhibits tumourigenesis is not yet fully understood. The mammalian type II GnRHIIR) is not translated in humans because of a premature stop codon in its sequence (Neill 2002). It has therefore been suggested that GnRH II might signal through the type I receptor in humans. Lu et al. (2005) have shown that both GnRH I and GnRH II can bind to the GnRHIR. Binding of each may stabilise different receptor active conformations and allow ligand-specific selective signalling. Silencing of GnRHIR in ovarian cancer cells has certainly been shown to reverse the antiproliferative effects of GnRH II (Kim et al. 2006). In contrast, Grundker et al. (2004) working in ovarian and endometrial cells have reported that the GnRHIR is not required for the inhibitory effects of GnRH II. One possibility is that the human GnRHIIR gene might produce incomplete transcripts and subsequently partial peptides that can form a GnRH II-responsive complex which may also involve GnRHIR (Neill et al. 2004). In support of this notion, Eicke et al. (2005) have identified a GnRHIIR-like protein in endometrial and ovarian cancer cells, while Maiti et al. (2005) have identified a novel GnRH II binding protein in prostate cancer cells. The intracellular effects of GnRH are mediated through $\mathrm{G}$ protein-coupled receptors (Millar et al. 2004). These in turn can recruit MAPKs that have a crucial role in GnRH intracellular signalling. The effects of GnRH II inhibition in ovarian cancer cells for instance have been shown to involve both ERK 1/2 and p38 MAPK (Kim et al. 2004, 2005). Protein kinase C is also though to be involved in this process (Kim et al. 2006). In breast cancer cells, GnRH II has been reported to block epidermal growth factor (EGF)dependent phosphorylation of the EGF receptor and subsequent recruitment of ERK1/2 (Gunthert et al. 2005). A novel mechanism of GnRH function was proposed by Chen et al. (2002b). In this study, GnRH II and GnRH I inhibited the expression of ribosomal phosphoproteins in human cancer cells. These are key regulators of protein elongation and suggest a role in regulating translation. It is possible that the mechanisms of GnRH II signalling may be cell and tissue type specific. The specific mechanisms involved in GnRH II binding and signalling in prostate cancer cells warrant further directed investigations, particularly in the light of the findings in this study, and are the subject of our current investigations.

In conclusion, in this report, we show first evidence that GnRH II is expressed in prostate cancer cells and is regulated by androgens. This induction requires the $A R$ that binds to a cognate response element in the gene. Our ongoing work is focused on further characterisation of this androgen response element, defining the mechanism of GnRH II binding and signalling in prostate cancer cells, the significance of the inhibitory effects of GnRH II in benign as well as androgen-dependent and androgenindependent prostate cancer cells and its potential value as a novel therapeutic agent.

\section{Funding}

Cancer Research UK. The authors declare that there is no conflict of interest that would prejudice the impartiality of this scientific work.

\section{References}

An BS, Choi JH, Choi KC \& Leung PC 2005 Differential role of progesterone receptor isoforms in the transcriptional regulation of human gonadotropin-releasing hormone I (GnRH I) receptor, GnRH I, and GnRH II. Journal of Clinical Endocrinology and Metabolism 90 1106-1113.

Belsham DD, Evangelou A, Roy D, Duc VL \& Brown TJ 1998 Regulation of gonadotropin-releasing hormone $(\mathrm{GnRH})$ gene expression by $5 \alpha$-dihydrotestosterone in $\mathrm{GnRH}$ secreting GT1-7 hypothalamic neurons. Endocrinology 139 1108-1114. 
Chen A, Laskar-Levy O, Ben-Aroya N \& Koch Y 2001 Transcriptional regulation of the human GnRH II gene is mediated by a putative cAMP response element. Endocrinology 142 3483-3492.

Chen A, Zi K, Laskar-Levy O \& Koch Y $2002 a$ The transcription of the $h G n R H-I$ and $h G n R H-I I$ genes in human neuronal cells is differentially regulated by estrogen. Journal of Molecular Neuroscience 18 67-76.

Chen A, Kaganovsky E, Rahimipour S, Ben-Aroya N, Okon E $\&$ Koch Y $2002 b$ Two forms of gonadotropin-releasing hormone $(\mathrm{GnRH})$ are expressed in human breast tissue and overexpressed in breast cancer: a putative mechanism for the antiproliferative effect of GnRH by down-regulation of acidic ribosomal phosphoproteins $\mathrm{P} 1$ and $\mathrm{P} 2$. Cancer Research 62 1036-1044.

Cheng CK, Hoo RL, Chow BK \& Leung PC 2003 Functional cooperation between multiple regulatory elements in the un-translated exon 1 stimulates the basal transcription of the human GnRH-II gene. Molecular Endocrinology 17 1175-1191.

Choi KC, Auersperg N \& Leung PC 2001 Expression and antiproliferative effect of a second form of gonadotropinreleasing hormone in normal and neoplastic ovarian surface epithelial cells. Journal of Clinical Endocrinology and Metabolism 86 5075-5078.

Choi JH, Choi KC, Auersperg N \& Leung PC 2006 Differential regulation of two forms of gonadotropinreleasing hormone messenger ribonucleic acid by gonadotropins in human immortalized ovarian surface epithelium and ovarian cancer cells. Endocrine-Related Cancer 13 641-651.

Cronauer MV, Schulz WA, Burchardt T, Anastasiadis AG, de la Taille A, Ackermann R \& Burchardt M 2003 The androgen receptor in hormone-refractory prostate cancer: relevance of different mechanisms of androgen receptor signalling. International Journal of Oncology 23 1095-1102.

Dondi D, Moretti RM, Montagnani Marelli M, Pratesi G, Polizzi D, Milani M, Motta M \& Limonta P 1998 Growthinhibitory effects of luteinizing hormone-releasing hormone (LHRH) agonists on xenografts of the DU 145 human androgen-independent prostate cancer cell line in nude mice. International Journal of Cancer 76 506-511.

Eicke N, Gunthert AR, Viereck V, Siebold D, Behe M \& Becker T 2005 GnRH-II receptor-like antigenicity in human placenta and in cancers of the human reproductive organs. European Journal of Endocrinology 153 605-612.

Gaughan L, Logan IR, Cook S, Neal DE \& Robson CN 2002 Tip60 and histone deacetylase 1 regulate androgen receptor activity through changes to the acetylation status of the receptor. Journal of Biological Chemistry 277 25904-25913.

Gnanapragasam VJ, Robson CN, Neal DE \& Leung HY 2002 Regulation of FGF8 expression by the androgen receptor in human prostate cancer. Oncogene 21 5069-5080.

Gnanapragasam VJ, Darby S, Khan MM, Lock WG, Robson CN \& Leung HY 2005 Evidence that prostate gonadotropin- releasing hormone receptors mediate an anti-tumourigenic response to analogue therapy in hormone refractory prostate cancer. Journal of Pathology 206 205-213.

Grossmann ME, Huang H \& Tindall DJ 2001 Androgen receptor signalling in androgen-refractory prostate cancer. Journal of the National Cancer Institute 93 1687-1697.

Grundker C, Gunthert AR, Millar RP \& Emons G 2002 Expression of gonadotropin-releasing hormone II (GnRH-II) receptor in human endometrial and ovarian cancer cells and effects of GnRH-II on tumor cell proliferation. Journal of Clinical Endocrinology and Metabolism 87 1427-1430.

Grundker C, Schlotawa L, Viereck V, Eicke N, Horst A, Kairies B \& Emons G 2004 Antiproliferative effects of the GnRH antagonist cetrorelix and of GnRH-II on human endometrial and ovarian cancer cells are not mediated through the GnRH type I receptor. European Journal of Endocrinology 151 141-149.

Gunthert AR, Grundker C, Olota A, Lasche J, Eicke N \& Emons G 2005 Analogs of GnRH-I and GnRH-II inhibit epidermal growth factor-induced signal transduction and resensitize resistant human breast cancer cells to $4 \mathrm{OH}-$ tamoxifen. European Journal of Endocrinology 153 613-625.

Halkidou K, Gnanapragasam VJ, Mehta PB, Logan IR, Brady ME, Cook S, Leung HY, Neal DE \& Robson CN 2003 Expression of Tip60, an androgen receptor co-activator, and its role in prostate cancer development. Oncogene $\mathbf{2 2}$ 2466-2477.

Horoszewicz JS, Leong SS, Kawinski E, Karr JP, Rosenthal H, Chu TM, Mirand EA \& Murphy GP 1983 LNCaP model of human prostatic carcinoma. Cancer Research 43 4809-4818.

Jemal A, Siegel R, Ward E, Murray T, Xu J, Smigal C \& Thun MJ 2006 Cancer statistics 2006. CA: A Cancer Journal for Clinicians 56 106-130.

Kang SK, Tai CJ, Nathwani PS \& Leung PC 2001 Differential regulation of two forms of gonadotropinreleasing hormone messenger ribonucleic acid in human granulosa-luteal cells. Endocrinology 142 182-192.

Khosravi S \& Leung PC 2003 Differential regulation of gonadotropin-releasing hormone $(\mathrm{GnRH}) \mathrm{I}$ and $\mathrm{GnRH}$ II messenger ribonucleic acid by gonadal steroids in human granulosa luteal cells. Journal of Clinical Endocrinology and Metabolism 88 663-672.

Kim D, Gregory CW, French FS, Smith GJ \& Mohler JL 2002 Androgen receptor expression and cellular proliferation during transition from androgen-dependent to recurrent growth after castration in the CWR22 prostate cancer xenograft. American Journal of Pathology 160 219-226.

Kim KY, Choi KC, Park SH, Chou CS, Auersperg N \& Leung PC 2004 Type II gonadotropin-releasing hormone stimulates p38 mitogen-activated protein kinase and apoptosis in ovarian cancer cells. Journal of Clinical Endocrinology and Metabolism 89 3020-3026. 
Kim KY, Choi KC, Park SH, Auersperg N \& Leung PC 2005 Extracellular signal-regulated protein kinase, but not $\mathrm{N}$-Jun N-terminal kinase, is activated by type II gonadotropin-releasing hormone involved in the inhibition of ovarian cancer cell proliferation. Journal of Clinical Endocrinology and Metabolism 90 1670-1677.

Kim KY, Choi KC, Auersperg N \& Leung PC 2006 Mechanism of gonadotropin-releasing hormone (GnRH)-I and -II-induced cell growth inhibition in ovarian cancer cells: role of the GnRH-I receptor and protein kinase C pathway. Endocrine-Related Cancer 13 211-220.

Limonta P, Moretti RM, Marelli MM, Dondi D, Parenti M \& Motta M 1999 The luteinizing hormone-releasing hormone receptor in human prostate cancer cells: messenger ribonucleic acid expression, molecular size, and signal transduction pathway. Endocrinology 140 5250-5256.

Ling MT, Chan KW \& Choo CK 2001 Androgen induces differentiation of a human papillomavirus $16 \mathrm{E} 6 / \mathrm{E} 7$ immortalized prostate epithelial cell line. Journal of Endocrinology 170 287-296.

Litvinov AntonyL IV, Dalrymple SL, Becker R, Cheng L \& Isaacs JT 2006 PC3, but not DU145, human prostate cancer cells retain the co-regulators required for tumour suppressor ability of androgen receptor. Prostate 66 1329-1338.

Lu ZL, Gallagher R, Sellar R, Coetsee M \& Millar RP 2005 Mutations remote from the human gonadotropin-releasing hormone $(\mathrm{GnRH})$ receptor-binding sites specifically increase binding affinity for GnRH II but not GnRH I: evidence for ligand-selective, receptor-active conformations. Journal of Biological Chemistry $28029796-29803$.

Maiti K, Oh DY, Moon JS, Acharjee S, Li JH \& Bai DG 2005 Differential effects of gonadotropin-releasing hormone (GnRH)-I and GnRH-II on prostate cancer cell signalling and death. Journal of Clinical Endocrinology and Metabolism 90 4287-4298.

Medeiros R, Morais A, Vasconcelos A, Costa S, Pinto D, Oliveira J, Carvalho R \& Lopes C 2002 Linkage between polymorphisms in the prostate specific antigen $A R E 1$ gene region, prostate cancer risk, and circulating tumour cells. Prostate 53 88-94.

Millar RP, Lu ZL, Pawson AJ, Flanagan CA, Morgan K \& Maudsley SR 2004 Gonadotropin-releasing hormone receptors. Endocrine Reviews 25 235-275.
Nathwani PS, Kang SK, Cheng KW, Choi KC \& Leung PC 2000 Regulation of gonadotropin-releasing hormone and its receptor gene expression by $17 \beta$-estradiol in cultured human granulosa-luteal cells. Endocrinology 141 1754-1763.

Neill JD $2002 G n R H$ and $G n R H$ receptor genes in the human genome. Endocrinology 143 737-743.

Neill JD, Musgrove LC \& Duck LW 2004 Newly recognized GnRH receptors: function and relative role. Trends in Endocrinology and Metabolism 15 383-392.

Roche PJ, Hoare SA \& Parker MG 1992 A consensus DNAbinding site for the androgen receptor. Molecular Endocrinology 6 2229-2235.

Rossi R, Zatelli MC, Franceschetti P, Maestri I, Magri E, Aguiari G, Cavazzini P, Uberti EC EC \& del Senno L 1996 Inhibitory effect of dihydrotestosterone on human thyroid cell growth. Journal of Endocrinology 151 185-194.

Rossi R, Zatelli MC, Valentini A, Cavazzini P, Fallo F, del Senno L \& degli Uberti EC 1998 Evidence for androgen receptor gene expression and growth inhibitory effect of dihydrotestosterone on human adrenocortical cells. Journal of Endocrinology 159 373-380.

Temple JL, Millar RP \& Rissman EF 2003 An evolutionarily conserved form of gonadotropin-releasing hormone coordinates energy and reproductive behavior. Endocrinology 144 13-19.

Wainstein MA, He F, Robinson D, Kung HJ, Schwartz S, Giaconia JM, Edgehouse NL, Pretlow TP, Bodner DR \& Kursh ED 1994 CWR22: androgen-dependent xenograft model derived from a primary human prostatic carcinoma. Cancer Research 54 6049-6052.

Wang Q, Carroll JS \& Brown M 2005 Spatial and temporal recruitment of androgen receptor and its co-activators involves chromosomal looping and polymerase tracking. Molecular Cell 19 631-642.

Whitacre DC, Chauhan S, Davis T, Gordon D, Cress AE \& Miesfeld RL 2002 Androgen induction of in vitro prostate cell differentiation. Cell Growth and Differentiation 13 1-11.

White RB, Eisen JA, Kasten TL \& Fernald RD 1998 Second gene for gonadotropin-releasing hormone in humans. PNAS 95 305-309. 